\title{
Native bee fauna of tomato crops: a comparison of active sampling and pan trapping methods
}

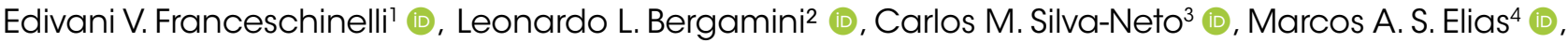

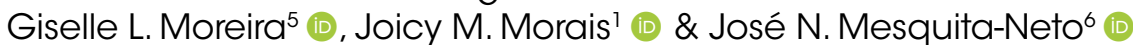

\author{
1. Departamento de Botânica, Instituto de Ciências Biológicas, Universidade Federal de Goiás, Campus Samambaia, Caixa Postal 131, 74001-970 Goiânia, GO, Brazil. \\ (edivanif@gmail.com) \\ 2. Centro de Estudos Ambientais do Cerrado, Reserva Ecológica do IBGE, DF-001, Km 38, 70312-970 Brasília, DF, Brazil. \\ 3. Instituto Federal de Educação, Ciência e Tecnologia de Goiás, 76600-000 Cidade de Goiás, GO, Brazil. \\ 4. Secretaria de Estado de Educação, Cultura e Esporte de Goiás, Av. Anhanguera, 7171, St. Oeste, 74110-010 Goiânia, GO, Brazil. \\ 5. Instituto de Ciências Biológicas, Universidade de Brasília, Campus Darcy Ribeiro - Asa Norte, 70910-900 Brasília, DF, Brazil. \\ 6. Departamento de Biología y Química, Facultad de Ciencias Básicas, Universidad Católica del Maule, Av. San Miguel, 3605, Talca, Chile.
}

Received 7 September 2018

Accepted 11 May 2019

Published 9 September 2019

DOI 10.1590/1678-4766e2019030

\begin{abstract}
The tomato is widely cultivated throughout the world and requires pollination by wild or managed bees to realize its full-potential fruit production. Two different sampling methods (pan trapping and active sampling) were employed in nine different properties from June to September of 2011 to investigate the richness and abundance of native bee species present in tomato crops of Center-West Brazil. A total of 465 individuals of 44 species were collected, with the composition of sampled bee species differing between the methods used. Twenty-two species were exclusively captured in pan traps, 13 others through active sampling and nine by both methods. Most of the sampled bee species can be considered effective pollinators of the tomato because they can perform buzz-pollination. By vibration, these bees can liberate pollen from anthers into the air or onto their own bodies and the stigmas of the same flower because the stigmas of the studied tomato variety are within the anther cone. Both methods exclusively sampled some species of buzz-pollinating bees, however, pan-trapping captured buzzing and non-buzzing visitors indiscriminately while active sampling captured more buzzing bees. Pan-trapping and active sampling appear to complement each other, and so the use of only one or the other would not provide a full understanding of the species richness of tomato pollinators in the field.
\end{abstract}

KEYWORDS. Ecosystem services, Exomalopsis, Solanum lycopersicum, tomato pollinators.

RESUMO. Fauna de abelhas nativa em plantações de tomate: uma comparação de métodos de amostragem ativa e de armadilha. O tomate é amplamente cultivado em todo o mundo e requer polinização por abelhas nativas ou manejadas para realizar o pleno potencial de produção dos frutos. Para investigar a riqueza e abundância de espécies de abelhas nativas em plantações de tomate do Centro-Oeste do Brasil, dois métodos de amostragem (armadilhas pan-trap e amostragem ativa) foram utilizados em nove propriedades de junho a setembro de 2011 . Um total de 465 indivíduos de 44 espécies foi coletado. A composição das espécies de abelhas amostradas diferiu dependendo do método utilizado. Vinte e duas espécies foram capturadas exclusivamente em armadilhas, 13 outras por meio de amostragem ativa e nove por ambos os métodos. A maioria das espécies de abelhas capturadas neste estudo pode ser considerada polinizadores eficazes do tomate, porque elas podem executar a polinização por vibração. Vibrando seus músculos torácicos, essas abelhas podem liberar o pólen das anteras para seus próprios corpos e para os estigmas da mesma flor, uma vez que eles estão dentro do cone de anteras da variedade do tomate estudado. Ambos os métodos amostraram espécies exclusivas de abelhas vibradoras. No entanto, as armadilhas capturaram abelhas vibradoras e não vibradoras indiscriminadamente e o método ativo amostrou principalmente a abelha vibradora. As coletas utilizando armadilhas e amostragens ativas foram complementares. O uso de apenas um método de amostragem não fornece um entendimento completo da riqueza de espécies de polinizadores de tomate no campo.

PALAVRAS-CHAVE. Serviços ecossistêmicos, Exomalopsis, Solanum lycopersicum, polinizadores de tomate.

The tomato plant (Solanum lycopersicum L., Solanaceae), originally from Andean regions, has many cultivars throughout the world (Peralta \& SpoOner, 2007). Brazil is the largest tomato producer in Latin America, with most of its production concentrated in states of Goiás, São Paulo, and Minas Gerais (DIEESE, 2010). Flowers of cultivated varieties of tomato have long poricidal anthers surrounding the pistil. They can be self-pollinated because the pistil is shorter than the stamens, and the stigma is very close to the apertures of the poricidal anthers. The poricidal anthers release a large amount of pollen when they are vibrated by bees, a process called buzz pollination (sensu BUCHMANN \& HURLEY, 1978). Visits by bees able to perform buzz behaviour in tomato flowers increases the dose of pollen received by the stigma as well as fruit set, size and weight (BANDA \& PAXTON, 1991; Morandin et al., 2001; GREENLEAF \& KREMEN, 2006; SiLVA-Neto et al., 2013). This fact makes the relationship between tomato crops and native pollinator bees important, since not all bees are able to vibrate the anthers, including Apis mellifera Linnaeus, 1758 (BANDA \& PAXTON, 1991; 
HARTER et al., 2002). Buzzing bees are stimulated to visit tomato flowers due to great efficiency with which they are able to extract pollen from them. However, the lack of the ability to vibrate flowers does not hamper pollen extraction and transfer to the stigma of poricidal flowers by non-buzzing bees, but they are much less efficient at pollen extraction than buzzing bees (De LuCa \& VALLEJo-Marín, 2013).

Pollinator faunas vary from one region to another, depending on the distance between regions and on the landscape where the crop is inserted. The main pollinators of organic tomato gardens in the state of California (United States of America) are the bees Anthophora urbana Cresson, 1878 and Bombus vosnesenskii Radoszkowski, 1862 (GREENLEAF \& Kremen, 2006), while bees of the genus Exomalopsis and Augocloropsis are considered efficient pollinators in Mexico (Macias-Macias et al., 2009). Bees of several families native to Brazil perform buzz pollination, namely Andrenidae, Apidae (except Apis), Colletidae, Halictidae and Megachilidae (Buchmann \& HurLey, 1978). Several species of these families visit and efficiently pollinate tomato flowers (Dogterom et al., 1998; Macias-Macias et al., 2009; Vergara \& FonseCA-Buendía, 2012; SiLva-Neto $e t$ al., 2013; SANTOS et al., 2014). Exomalopsis (Exomalopsis) analis Spinola, 1853 has been reported to be the most common bee species in tomato crops of Brazil (SILVA-NETO et al., 2013; SANTOS et al., 2014).

Observed richness and abundance of pollinators also varies considerably according to sampling effort and method (Westrhal et al., 2008; Popic et al., 2013). Active sampling (using entomological nets) has been the most commonly used method, however, pan-trapping has become viewed as an attractive alternative to traditional net collecting because it is cheaper, requires fewer person-hours, is not dependent on trained collectors, and presumably eliminates collector bias (e.g., Westphal et al., 2008; GonÇALVEs \& Oliveira, 2013). Furthermore, global decline in pollination services has stimulated rapid surveys of flower-visiting invertebrates using net sampling complemented with pan traps (PopIC et al., 2013). However, there is controversy regarding the specificity of pan-trapping, and studies have shown that pan traps do not capture only pollinators (PoPIC et al., 2013). There has yet to be a study using pan traps to capture pollinators in tomato crops, and so it is not clear whether pan trapping is efficient for collecting tomato flower pollinators in tomato crops.

Therefore, the objective of this study was to compare the species composition, richness and abundance of pollinators sampled in tomato crops using two capture methods: active sampling with entomological nets and pantrapping. Additionally, whether pan traps of different colors catch different bee species was tested by comparing white, yellow and blue pan traps. Pan-trapping was hypothesized to collect a greater abundance and diversity of bees than active sampling, and thus prove to be a more efficient and rapid method for sampling pollinators of tomato flowers.

\section{MATERIAL AND METHODS}

Study area. The areas studied were staked tomato crops used to produce conventional fresh tomatoes of Italian varieties. Nine crop areas in the municipalities of Anápolis, Bonfinópolis, Senador Canedo, Leopoldo de Bulhões, Nerópolis, and Goianápolis (state of Goiás, Brazil) were selected for sampling (Fig. 1, Tab. I). The crop areas were quite isolated within a uniform matrix composed mainly of cattle pasture (FrANCESCHINELLI et al., 2017). Pan-trapping and active collecting were performed from 16 June to 29 September 2011, which is the dry period in Center-West Brazil and when the tomato is most commonly cultivated in the region. This sampling period was also chosen because it corresponds to the period with the greatest abundance of bees, as reported by SiLVA-NeTo et al. (2016) in the same crop area. The sampled crops had between 20,000 to 50,000 tomato plants planted in rows spaced $1.2 \mathrm{~m}$ apart. Each row had 30 plants spaced $1 \mathrm{~m}$ apart that were staked using bamboos.

Sampling method and design. Each crop area had four rows of tomato plants at the center of the crop actively sampled for tomato flower pollinators every 30 minutes from 09:00 to 13:00 h. Active sampling was performed by the same two persons and occurred for two days in each area, for a total of $8 \mathrm{~h}$ of active sampling per area. Floral visitors were observed prior to being collected with an entomological net to determine whether pollen was collected by vibration during their visits. Individuals were later identified in the laboratory of Plant Reproductive Biology at the Federal University of Goiás with the help of the bee taxonomists from the Universidade Federal de Minas Gerais (Dr. Fernando A. Silveira) and Universidade Federal da Bahia (Dr. Favízia F. de Oliveira). Vouchers specimens were deposited in the bee collections of Universidade Federal de Minas Gerais and Universidade Federal da Bahia.

Bees of the same crop areas, and during the same period, were collected using pan traps (Роттs et al., 2005). These traps consisted of small containers $(200 \mathrm{~mL})$ painted with UV-bright fluorescent blue or yellow paint (Colorgin(C) Sherwin-William) or left white (the reflectance of each color was not quantified in this study). The traps contained water and mild detergent to break the surface tension of the water so as to entrap the pollinators, which were attracted by the reflected light. The traps were set on tomato stakes at a height of $1.5 \mathrm{~m}$ in the late afternoon and left for $24 \mathrm{~h}$. A total of 30 traps (10 of each color) were distributed $1.2 \mathrm{~m}$ apart from each other near the center of each crop area with colors placed alternately. Pan-trap sampling was performed once in each area with the captured bees being separated for subsequent identification. Pan-trapping and active samplings were done on days without pesticide application.

Statistical analyses. We used GLMMs (BOLKER et al., 2009) with Poisson distribution to test whether observed bee species richness and abundance differed between pan trapping and active sampling. Differences in bee species composition of the samples were also assessed using nonparametric Multivariate Analysis of Variance (PERMANova 


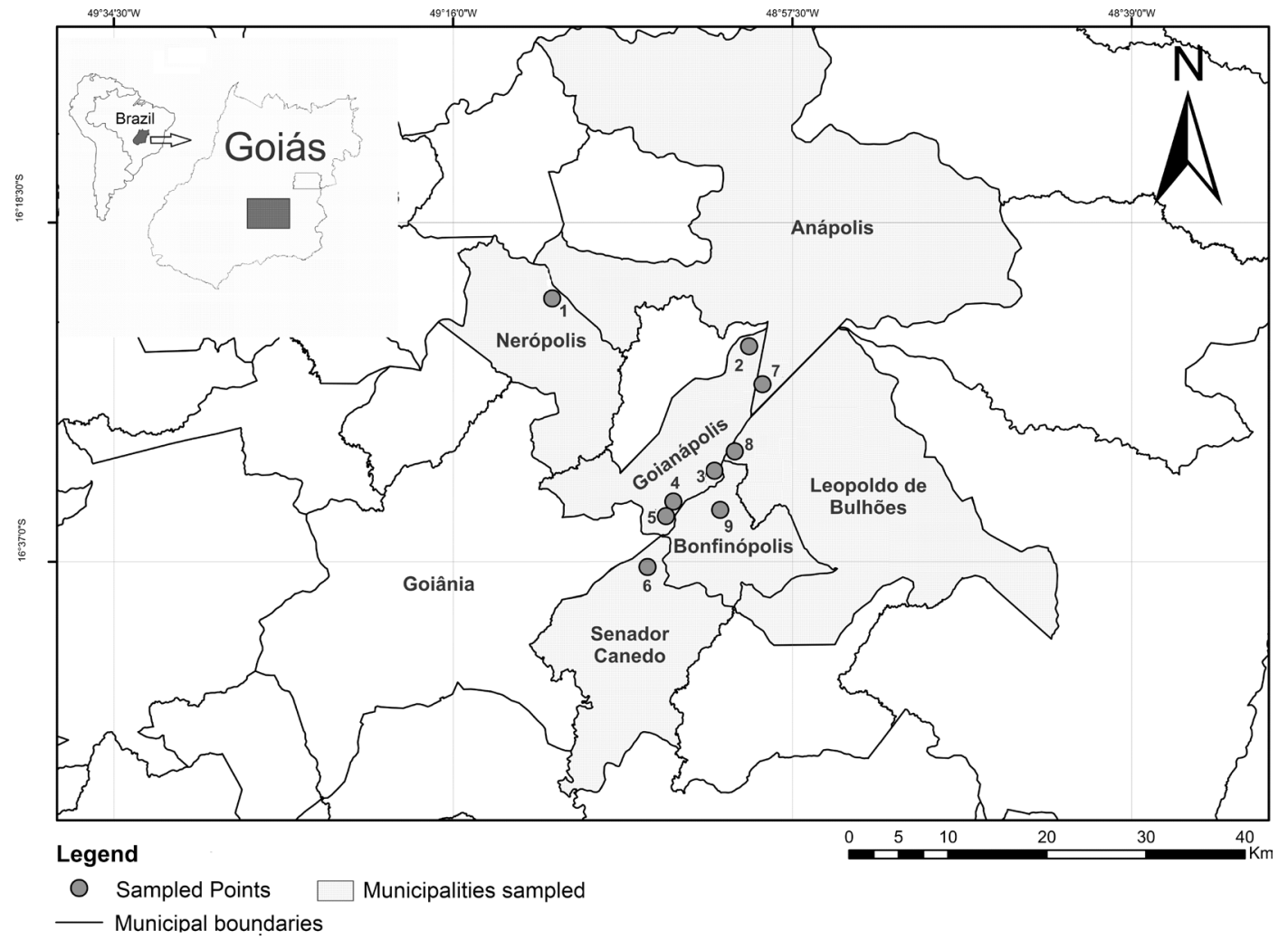

Fig. 1. Map of the study crops in state of Goiás, Brazil.

Tab. I. Geographic coordinates of the tomato crops where bees were sampled using active sampling (entomological net) and pan trapping, state of Goiás, Brazil.

\begin{tabular}{|c|c|c|c|}
\hline Numbers in Fig. 1 & Municipalities & Geographic coordinates (DMS) & Altitude $(\mathrm{m})$ \\
\hline 01 & Nerópolis & $49^{\circ} 10^{\prime} 35^{\prime \prime} \mathrm{W}, 16^{\circ} 22^{\prime} 39^{\prime \prime} \mathrm{S}$ & 907 \\
\hline 02 & Goianápolis & $48^{\circ} 59^{\prime} 52^{\prime \prime} \mathrm{W}, 16^{\circ} 25^{\prime} 15^{\prime \prime} \mathrm{S}$ & 1053 \\
\hline 03 & Goianápolis & $49^{\circ} 01^{\prime} 45^{\prime \prime} \mathrm{W}, 16^{\circ} 32^{\prime} 03^{\prime \prime} \mathrm{S}$ & 936 \\
\hline 04 & Goianápolis & $49^{\circ} 03^{\prime} 58^{\prime \prime} \mathrm{W}, 16^{\circ} 33^{\prime} 44^{\prime \prime} \mathrm{S}$ & 965 \\
\hline 05 & Goianápolis & $49^{\circ} 04^{\prime} 23^{\prime \prime} \mathrm{W}, 16^{\circ} 34^{\prime} 32^{\prime \prime} \mathrm{S}$ & 938 \\
\hline 06 & S. Canedo & $49^{\circ} 05^{\prime} 24^{\prime \prime} \mathrm{W}, 16^{\circ} 37^{\prime} 18^{\prime \prime} \mathrm{S}$ & 859 \\
\hline 07 & Anápolis & $48^{\circ} 59^{\prime} 08^{\prime \prime} \mathrm{W}, 16^{\circ} 27^{\prime} 19^{\prime \prime} \mathrm{S}$ & 933 \\
\hline 08 & L. Bulhões & $49^{\circ} 00^{\prime} 38^{\prime \prime} \mathrm{W}, 16^{\circ} 30^{\prime} 59^{\prime \prime} \mathrm{S}$ & 989 \\
\hline 09 & Bonfinópolis & $49^{\circ} 01^{\prime} 26^{\prime \prime} \mathrm{W}, 16^{\circ} 34^{\prime} 12^{\prime \prime} \mathrm{S}$ & 919 \\
\hline
\end{tabular}

- ANDERSON, 2001) with a Bray-Curtis dissimilarity matrix and randomization stratified by tomato crop area.

In addition, a one-way ANOVA was carried out to compare richness and abundance of the bees sampled using the three different pan trap colors and another MANOVA to test for differences in composition among colors. Both the ANOVA and the MANOVA comparing colors also contained tomato crop as a blocking factor. Post-hoc tests (Tukey's HSD for the ANOVA and Bonferroni-corrected pairwise comparisons for MANOVA) were used to evaluate which levels differed in the case of a significant main effect. All analyses were performed in the R environment ( $R$ CORE TEAM,
2015). Sample completeness was computed using the package iNEXT (CHAO et al., 2014; HsIEH et al., 2019). GLMM were fitted using the package lme4 (BATES et al., 2015).

\section{RESULTS}

A total of 465 individual bees were captured of 44 species of four families. A total of 22 species were exclusive to pan traps and 13 to active sampling, whereas nine species were captured by both methods. A total of 295 individuals were collected in pan traps and 170 by active sampling. Bees able to vibrate the anthers of tomato flowers were considered potential pollinators (Tab. II). 
Tab. II. Bees collected in flowers of tomato crops in state of Goiás, Brazil, using the methods of active sampling (AS) and pan trapping (PT) from 16 June to 29 September 2011. Bee behavior on tomato flowers: (V) bees that vibrate anthers; (NV) bees that do not vibrate anthers.

\begin{tabular}{|c|c|c|c|c|c|c|}
\hline \multirow{2}{*}{ Bee species } & \multirow{2}{*}{$\begin{array}{l}\text { Type of } \\
\text { visitor }\end{array}$} & \multicolumn{2}{|c|}{ Abundance } & \multicolumn{3}{|c|}{ Richness } \\
\hline & & AS & PT & AS & $\mathrm{PT}$ & AS and PT \\
\hline \multicolumn{7}{|l|}{ APIDAE } \\
\hline Apis mellifera Linnaeus, 1758 & $\mathrm{NV}$ & & 13 & & 1 & \\
\hline Apidae sp. 1 & $?$ & 1 & 2 & 1 & 1 & 1 \\
\hline Apidae sp. 2 & $?$ & & 1 & & 1 & \\
\hline Apidae sp. 3 & $?$ & & 1 & & 1 & \\
\hline Bombus (Fervidobombus) morio Swederus, 1787 & $\mathrm{~V}$ & & 1 & & 1 & \\
\hline Centris (Hemisiella) sp. & $\mathrm{V}$ & 1 & & 1 & & \\
\hline Centris (Centris) aenea Lepeletier, 1841 & $\mathrm{~V}$ & 1 & & 1 & & \\
\hline Centris cf. fuscata Lepeletier, 1841 & $\mathrm{~V}$ & 2 & & 1 & & \\
\hline Ceratina (Crewella) cuprifrons Strand, 1910 & $?$ & & 1 & & 1 & \\
\hline Diadasina sp. & $?$ & & 6 & & 1 & \\
\hline Epicharis (Epicharana) flava Friese, 1900 & $\mathrm{~V}$ & & 1 & & 1 & \\
\hline Epicharis (Epicharis) sp. & $\mathrm{V}$ & & 1 & & 1 & \\
\hline Euglossa sp. & $\mathrm{V}$ & & 4 & & 1 & \\
\hline Eulaema (Apeulema) nigrita Lepeletier, 1841 & $\mathrm{~V}$ & 6 & & 1 & & \\
\hline Exomalopsis (Exomalopsis) analis Spinola, 1853 & $\mathrm{~V}$ & 73 & 47 & 1 & 1 & 1 \\
\hline Exomalopsis (Exomalopsis) auropilosa Spinola, 1853 & $\mathrm{~V}$ & 7 & 8 & 1 & 1 & 1 \\
\hline Exomalopsis (Exomalopsis) minor Schrottky, 1919 & $\mathrm{~V}$ & & 3 & & 1 & \\
\hline Exomalopsis sp. & $\mathrm{V}$ & 2 & 2 & 1 & 1 & 1 \\
\hline Exomalopsis (Exomalopsis) fulvofasciata Smith, 1879 & $\mathrm{~V}$ & 2 & 6 & 1 & 1 & 1 \\
\hline Frieseomellita sp. & $\mathrm{NV}$ & 1 & & 1 & & \\
\hline Geotrigona subterranea (Friese, 1901) & $\mathrm{V}$ & 8 & 2 & 1 & 1 & 1 \\
\hline Melipona (Melikerria) quinquefasciata Lepeletier, 1836 & $\mathrm{~V}$ & & 1 & & 1 & \\
\hline Melitomella $\mathrm{sp}$ & $\mathrm{NV}$ & & 3 & & 1 & \\
\hline Paratrigona lineata (Lepeletier, 1836) & $\mathrm{V}$ & 13 & 7 & 1 & 1 & 1 \\
\hline Tetragonisca angustula Latreille, 1811 & NV & 1 & & 1 & & \\
\hline \multicolumn{7}{|l|}{ HALICTIDAE } \\
\hline Augochloropsis callichroa (Cockerell, 1900) & $\mathrm{V}$ & 4 & & 1 & & \\
\hline Augochloropsis smithiana (Cockerell, 1900) & $\mathrm{V}$ & 2 & & 1 & & \\
\hline Augochloropsis sp. 1 & $\mathrm{~V}$ & & 2 & & 1 & \\
\hline Augochloropsis sp. 2 & $\mathrm{~V}$ & 26 & 2 & 1 & 1 & 1 \\
\hline Augochloropsis sp. 3 & $\mathrm{~V}$ & 1 & & 1 & & \\
\hline Augochloropsis sp. 4 & $\mathrm{~V}$ & 1 & & 1 & & \\
\hline Augochloropsis sp. 5 & $\mathrm{~V}$ & 3 & & 1 & & \\
\hline Dialictus sp. & $\mathrm{NV}$ & 4 & 130 & 1 & 1 & 1 \\
\hline Halictidae sp. 1 & $\mathrm{~V}$ & & 8 & & 1 & \\
\hline Halictidae sp. 2 & $\mathrm{~V}$ & & 4 & & 1 & \\
\hline Halictidae sp. 3 & $\mathrm{~V}$ & & 2 & & 1 & \\
\hline Halictidae sp. 4 & $\mathrm{~V}$ & & 1 & & 1 & \\
\hline Halictidae sp. 5 & $\mathrm{~V}$ & & 19 & & 1 & \\
\hline Halictus sp. & $?$ & & 12 & & 1 & \\
\hline Pseudaugochlora sp. 1 & $\mathrm{~V}$ & 6 & & 1 & & \\
\hline Pseudaugochlora sp. 2 & $\mathrm{~V}$ & 5 & & 1 & & \\
\hline \multicolumn{7}{|l|}{ MEGACHILIDAE } \\
\hline Megachile (Sayapis) sp. & $\mathrm{V}$ & & 3 & & 1 & \\
\hline Megachile (Leptorachina) laeta Smith, 1853 & $\mathrm{~V}$ & & 1 & & 1 & \\
\hline \multicolumn{7}{|l|}{ ANDRENIDAE } \\
\hline Oxaea flavescens Klug, 1807 & $\mathrm{~V}$ & & 1 & & 1 & \\
\hline Total & & 170 & 295 & 22 & 31 & 9 \\
\hline
\end{tabular}


The two sampling methods differed in sampled bee species richness and abundance with both richness $(\mathrm{z}=$ $-2.57, \mathrm{p}=0.01)$ and abundance $(\mathrm{z}=-5.748, \mathrm{p}<0.001)$ being greater for pan-trapping (Tab. III). Pan trapping collected on average 3.2 times more species and 13.9 times more individuals per area than active sampling. In addition, pantrapping captured more species of buzzing bees (22 spp.) with lower abundance ( 126 specimens), than active sampling (18 spp., 163 individuals) (Tab. II). While pan-trapping captured similar abundances of buzzing (126 specimens) and nonbuzzing bees (146 specimens), active sampling captured a greater abundance of buzzing bees (163 specimens) than non-buzzing (6 specimens) (Tab. II). Observed species composition also differed between the sampling methods $\left(\mathrm{F}_{\text {MANOVA }}=3.14, \mathrm{p}=0.01\right.$; Tab. II $)$. Pan-trapping sampled a greater proportion of exclusive species of buzzing bees (15 spp.) than active sampling (9 spp.; Tab. II). Despite the differences in species composition, both methods achieved a high sample completeness (Active sampling $=0.959(0.937-$ 0.982), Pan trap $=0.966(0.949-0.984))$.

No differences were observed in bee richness $\left(\mathrm{F}_{(2,24)}\right.$ $=2.02, \mathrm{p}>0.05$, Fig. 2$)$ and abundance $\left(\mathrm{F}_{(2,24)}=0.615, \mathrm{p}>\right.$ 0.05 , Fig. 3 ) among pan trap colors. There was, however, a difference in species composition between bee samples of the yellow and blue traps (Global test $\mathrm{F}=2.28, \mathrm{p}=0.002$, Tab. IV).

Tab. III. Results of GLMMs with Poisson distribution results, showing that observed bee species richness and abundance differed between pan trapping and active sampling.

\begin{tabular}{|c|c|c|c|c|c|c|}
\hline & \multicolumn{3}{|c|}{$\begin{array}{c}\text { Richness } \\
\text { Area random effect variance }<0.001 \\
18 \text { observations on } 9 \text { groups }\end{array}$} & \multicolumn{3}{|c|}{$\begin{array}{c}\text { Abundance } \\
\text { Area random effect variance }=0.348 \\
18 \text { observations on } 9 \text { groups }\end{array}$} \\
\hline & Estimate & Z & $\mathrm{P}$ & Estimate & $\mathrm{Z}$ & $\mathrm{P}$ \\
\hline Intercept & 2.147 & 18.84 & $<0.001$ & 3.309 & 15.977 & $<0.001$ \\
\hline Ative vs Pantrap & -0.473 & -2.57 & 0.0102 & -0.551 & -5.748 & $<0.001$ \\
\hline
\end{tabular}

Tab. IV. Comparison of the composition of bee species sampled in flowers of tomato crops (state of Goiás, Brazil) by different colored pan traps. Statistical test: MANOVA, P-values $\leq 0.05$ (in bold) indicates significant differences for the contrasts. Contrasts were adjusted by Bonferroni correction.

\begin{tabular}{lccc}
\hline & $\mathrm{F}$ & $\mathrm{R}^{2}$ & $\mathrm{P}$ \\
\hline Global test & & & $\mathbf{0 . 0 0 2}$ \\
Color & 2.280 & 0.17 & $\mathbf{0 . 0 0 6}$ \\
Contrast & & & 0.156 \\
Yellow vs Blue & 3.963 & 0.11 & 0.924 \\
Yellow vs White & 2.053 & 0.07 & \\
Blue vs White & 1.132 & & \\
\hline
\end{tabular}
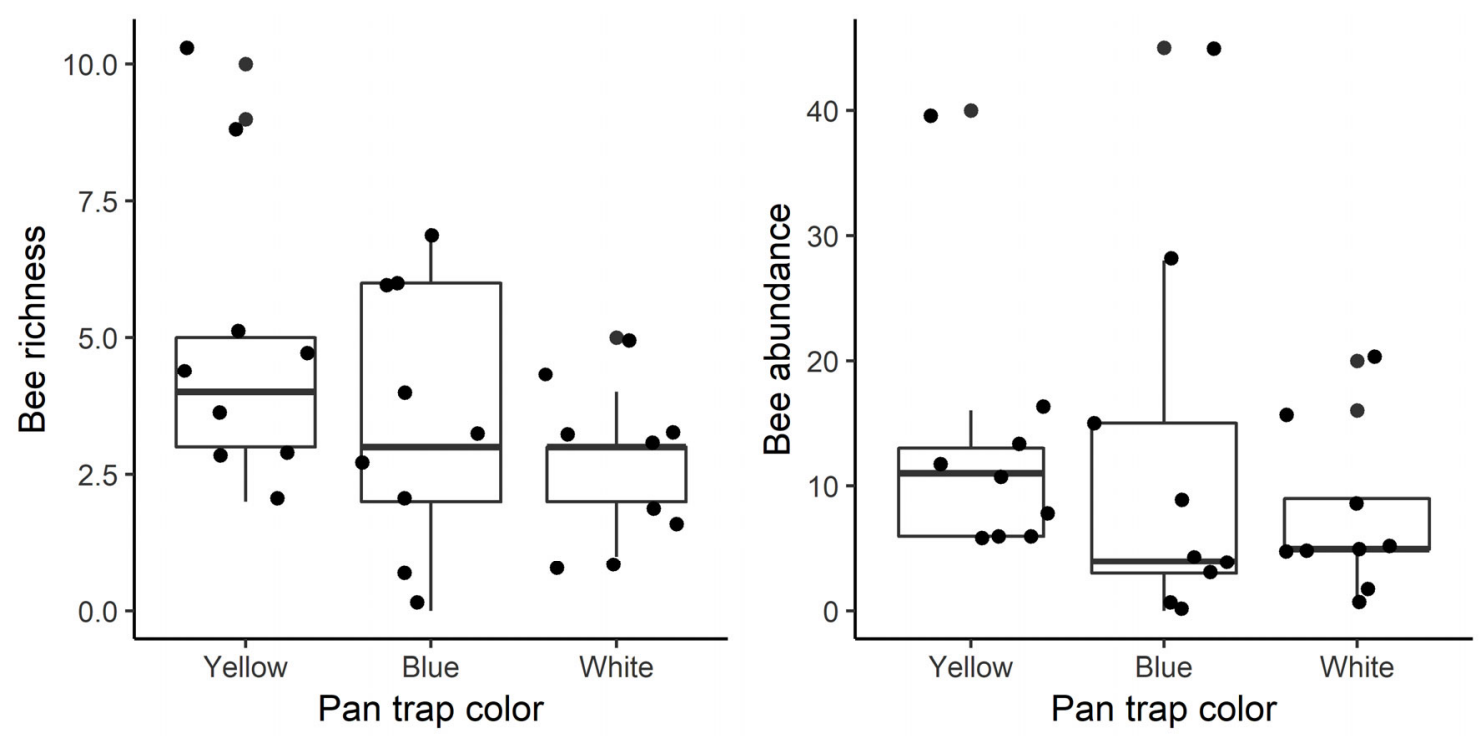

Figs 2, 3. Richness (Fig. 2) and abundance (Fig. 3) of flower visiting bees sampled by different pan trap colors in nine tomato crops in Goiás state, Brazil. Boxplots represent means while vertical lines represent the $95 \%$ confidence interval. Each point represents value for each sampling unit. 


\section{DISCUSSION}

Observed bee species composition differed between active sampling and pan-trapping, with each sampling mutually exclusive species. Visitors able to vibrate tomato flower anthers were collected by both methods. Thus, the two methods appear to complement each other in surveying the pollinator community of tomato crops. Pan traps likely sampled species that were difficult to capture by active sampling, perhaps because they were rarer, more agile, or foraged at time periods other than that of active sampling, such as Bombus (Fervidobombus) morio Swederus, 1787, Epicharis spp., Euglossa sp., Melipona (Melikerria) quinquefasciata Lepeletier, 1836, Megachilidae spp., and Oxaea flavescens Klug, 1807, among others.

The greater bee species abundance and richness captured by pan-trapping may be because the traps were distributed in the center of the crops and exposed for a period of 24 hours, whereas active sampling occurred on just two days by one person for only a four-hour period each day (09:00 to 13:00 h) in each crop. In fact, several species, such as those mentioned above, were seen visiting tomato flowers during or after the period of data collection but were unable to be collected by entomological net. Thus, species composition of samples of the two methods differed significantly (see also PoPIC et al., 2013), with pan-trapping being more efficient at capturing bees (e.g., ABRAHAMCZYK et al., 2010). Some other studies found different results, showing that active sampling may catch more species in a higher abundance than pan-trapping (e.g., PoPIC et al., 2013).

Species of Bombus Latreille, 1802, Epicharis Klug, 1807, Euglossa Latreille, 1802, Eulaema Lepeletier, 1841, Exomalopsis Spinola, 1853, Megachile Latreille, 1802, Melipona Illiger, 1806, Oxaea Krug, 1807, Augochlora Smith, 1853, and Pseudaugochlora Michener, 1954, among others, perform the buzz pollination behavior and visit tomato flowers (BANDA \& PAXTON, 1991; Kevan et al., 1991; NunesSilva et al., 2010; Silva-Neto et al., 2016). Some species of these genera [e.g., Exomalopsis (Exomalopsis) analis Spinola, 1853 and Augochloropsis sp.] were the most commonly captured species using active sampling, and were frequently observed vibrating the tomato flowers (SILVA-NeTo et al., 2016), and thus are certainly the most important pollinators of the studied tomato crops. Pan trapping sampled species such as Bombus morio, Euglossa sp., Melipona quinquefasciata, Megachile ssp., Oxaea flavescens and several species of the family Halictidae that are potential pollinators of tomato plants (SILVA-NeTo et al., 2016). The richness and abundance of captured buzzing bees differed between the sampling methods. Pan-trapping captured similar abundances of buzzing and non-buzzing bees, while active sampling captured a greater abundance of buzzing than non-buzzing bees. However, pan-trapping sampled a greater richness of buzzing bees with a greater proportion of exclusive species. Thus, while pan-trapping captured buzzing and non-buzzing visitors indiscriminately, active sampling tended to sample more buzzing-bees. The use of pan-trapping in association with active sampling resulted in a considerable increase in the sampled richness and abundance of potential tomato pollinators in the study areas.

There were no differences in mean abundance or richness among the different pan trap colors, but there was a difference in the composition sampled by the blue and yellow traps. Species of Exomalopsis, for example, showed a preference for the blue traps, with more than $80 \%$ of the individuals of this genus being captured pan traps of this color. Dialictus sp., however, was the bee species most sampled by the pan trap method. Dialictus sp. and Paratrigona lineata (Lepeletier, 1836) are able to perform buzz pollination, but are too small to be able to vibrate the tomato flower. Hence, these bees ended up gathering pollen grains that were already out of the anther due to the vibration of other bees. Species that are not capable of performing buzz pollination, such as A. mellifera, Frieseomellita sp., Geotrigona subterranea (Friese, 1901), and Tetragonisca angustula Latreille, 1811 (MichENER, 1962; BUCHMANN \& Hurley, 1978; Banda \& Paxton, 1991; Harter et al., 2002; Cauich et al., 2004; NunEs-Silva et al., 2010), were also collected in this study. Studies have shown that some non-buzzing species are able to increase pollination service in tomato crops, although with less efficiency than buzzing species (De Luca \& Vallejo-Marín, 2013). Non-buzzing bees were captured by both sampling methods and may contribute to tomato production in the studied areas.

As expected, pan trapping proved to be an important method for sampling tomato flower pollinators. The use of pan traps should be encouraged since it is a quick and practical method for sampling flower visitors. However, it is complementary to active sampling because active sampling captured bee species actually observed on flowers and often species not sampled by pan trapping, including those considered effective pollinators of tomato flowers. While pan-trapping captured buzzing and nonbuzzing visitors indiscriminately, active sampling tended to capture more buzzing bees. The data presented here are of extreme importance for proposing bee management and conservation strategies to governamental agencies, as well as to establishing friendly practices with tomato producers in the state of Goiás and other areas where tomatoes are produced and such species occur.

Acknowledgments. We thank to two anonymous reviewers for their constructive comments, which improved the manuscript. This work was supported by the National Council for Scientific and Technological Development - CNPq (Process \#556057/2009-0).

\section{REFERENCES}

AbrahamczyK, S.; Steudel, B. \& Kessler, M. 2010. Sampling Hymenoptera along a precipitation gradient in tropical forests: the effectiveness of different coloured pantraps. Entomologia Experimentalis et Applicata 137:262-268.

Anderson, M. J. 2001. A new method for non-parametric multivariate analysis of variance. Austral Ecology 26:32-34.

Banda, H. J. \& Paxton, R. J. 1991. Pollination of greenhouse tomatoes by bees. Acta Horticulturae 288:194-198. 
Bates, D.; Bolker, B. \& Walker, S. 2015. Fitting Linear Mixed-Effects Models using lme4. Journal of Statistical Software 67:1-48.

Bolker, B. M.; Brooks, M. E.; Clarc, C. J.; Geange, S. W.; Poulsen, J. R.; Stevens, M. H. H. \& White, J. S. S. 2009. Generalized linear mixed models: a practical guide for ecology and evolution. Trends in Ecology \& Evolution 24:127-135.

BuchmanN, S. L. \& Hurley, J. P. 1978. A biophysical model for buzz pollination in angiosperms. Journal of Theoretical Biology 72:639657.

Cauich, O.; Quezada-Eú́n, J. J.; Macias-Macias, J. O.; Reyes-Oregel, V.; Medina-Peralta, S. \& Parra-Tabla, V. 2004. Behavior and pollination efficiency of Nannotrigona perilampoides (Hymenoptera: Meliponini) on greenhouse tomatoes (Lycopersicum esculentum) in Subtropical México. Journal of Economic Entomology 97:475-481.

Chao, A.; Gotelli, N. J.; Hsieh, T. C.; Sander, E. L.; Ma, K. H.; Colwell, R. K. \& ElLison, A. M. 2014. Rarefaction and extrapolation with hill numbers: a framework for sampling and estimation in species diversity studies. Ecological Monographs 84:45-67.

De Luca, P. A. \& Vallejo-Marín, M. 2013. What's the 'buzz' about? The ecology and evolutionary significance of buzz-pollination. Current Opinion in Plant Biology 16:429-435.

DIEESE, 2010. A produção mundial e brasileira de tomate. Goiânia: DIEESE - Departamento Intersindical de Estatística e Estudos Socioeconômicos. Available at $<$ https://www.dieese.org.br/projetos/ informalidade/estudoSobreAproducaoDeTomateIndustrialNoBrasil. pdf $>$. Accessed on 22 July 2011.

Dogterom, M. H.; Matteoni, J. A. \& Plowright, R. C. 1998. Pollination of greenhouse tomatoes by the North American Bombus vosnesenskii (Hymenoptera: Apidae). Journal of Economic Entomology 91:71-75.

Franceschinelli, E. V.; Elias, M. A.; Bergamini, L. L.; Silva-Neto, C. M. $\&$ SUIII, E. R. 2017. Influence of landscape context on the abundance of native bee pollinators in tomato crops in Central Brazil. Journal of Insect Conservation 21:715-726.

Gonçalves, R. B. \& Oliveira, P. S. 2013. Preliminary results of bowl trapping bees (Hymenoptera, Apoidea) in a southern Brazil forest fragment. Journal of Insect Biodiversity 1:1-9.

Greenleaf, S. S. \& Kremen, C. 2006. Wild bee species increase tomato production and respond differently to surrounding land use in Northern California. Biological Conservation 13:81-87.

Harter, B.; Leistikow, C.; Wilms, W.; Truylio, B. \& Engels, W. 2002. Bees collecting pollen from flowers with poricidal anthers in a south Brazilian Araucaria forest: a community study. Journal of Apicultural Research 40:9-16.

Hsieh, T. C.; Ma, K. H. \& ChaO, A. 2019. iNEXT: iNterpolation and EXTrapolation for species diversity. R package version 2.0.19

Kevan, P. G.; Straver, W. A.; Offer, M. \& Laverty, T. M. 1991. Pollination of greenhouse tomatoes by bumble bees in Ontario. Proceedings of the Entomological Society of Ontario 122:15-19.
Macias-Macias, O.; Chuc, J.; Ancona-Xiu, P.; Cauich, O. \& QuezadaEuÁN, J. J. G. 2009. Contribution of native bees and Africanized honey bees (Hymenoptera: Apoidea) to Solanaceae crop pollination in tropical México. Journal of Applied Entomology 133:456-465.

Michener, C. D. 1962. Biological observations on the primitively social bees of the genus "Allodapula" in the Australian region (Hymenoptera, Xylocopinae). Insectes Sociaux 4:423-434.

Morandin, L. A.; Laverty, T. M. \& Kevan, P. G. 2001. Effect of bumble bee (Hymenoptera: Apidae) pollination intensity on the quality of greenhouse tomatoes. Journal of Economic Entomology 94:172-179.

Nunes-Silva, P.; Hrncir, M. \& Imperatriz-Fonseca, V. L. 2010. A Polinização por Vibração. Oecologia Australis 14:140-151.

Peralta, I. E. \& Spooner, D. M. 2007. History, origin and early cultivation of tomato (Solanaceae). In: Razdan, M. K. \& Mattoo, A. K. eds. Genetic Improvement of Solanaceous Crops. Vol. 2. Enfield, Science Publishers, p. 1-27.

Popic, T. J.; Davila, Y. C. \& Wardle, G. M. 2013. Evaluation of common methods for sampling invertebrate pollinator assemblages: net sampling out-perform pan traps. PLoS One 8:e66665.

Potts, S. G.; Kevan, P. G. \& Boone, J. W. 2005. Conservation in Pollination: Collecting, surveying and monitoring. In: DAFNI, A. \& Kevan, P. eds. Pollination ecology: a practical approach. Cambridge, Enviroquest, p. 401-434.

R Core Team. 2015. R: A language and environment for statistical computing. R Foundation for Statistical Computing, Vienna. Available at $<$ http://www.R-project.org/>. Accessed on 16 October 2016.

Santos, A. O. R.; Bartelli, B. F. \& Nogueira-Ferreira, F. H. 2014. Potential pollinators of tomato, Lycopersicon sculentum (Solanaceae), in open crops and the effect of a solitary bee in fruit set and quality. Journal of Economic Entomology 107:987-994.

Silva-Neto, C.; Gomes, F. L.; Gonçalves, B. B.; Bergamini, L.; Bergamini, B.; Elias, M. A. S. \& Franceschinelli, E. V. 2013. Native bees pollinate tomato flowers and increase fruit production. Journal of Pollination Ecology 11:41-45.

Silva-Neto, C. M.; Bergamini, L. L.; Elias, M. A. S.; Moreira, G. L.; Morais, J. M.; Bergamini, B. A. R. \& Franceschinelli, E. V. 2016. High species richness of native pollinators in Brazilian tomato crops. Brazilian Journal of Biology 3:506-513.

Vergara, C. H. \& Fonseca-Buendía, P. 2012. Pollination of greenhouse tomatoes by the Mexican bumblebee Bombus ephippiatus (Hymenoptera: Apidae). Journal of Pollination Ecology 7:27-30.

VRDOLJAK, S. M. \& SamwaYs, M. J. 2011. Optimising coloured pan traps to survey flower visiting insects. Journal of Insect Conservation 16:345-354.

Westphal, C.; Bommarco, R.; Carré, G.; Lamborn, E.; Morison, N.; Petanidou, T.; Potts, S. G.; Roberts, S. P.; Szentgyörgyi, H.; Tscheulin, T. \& VAissière, B. E. 2008. Measuring bee diversity in different European habitats and biogeographical regions. Ecological Monographs 78:653-671. 